\title{
Conceptual Understanding and Mathematical Representation Analysis of Realistic Mathematics Education Based on Personality Types
}

\author{
Kowiyah, Mulyawati. I ${ }^{1}$, Khoerul Umam² \\ ${ }^{1,2}$ Universitas Muhammadiyah Prof. DR. HAMKA \\ ${ }^{2}$ Correspondence Address; khoerul.umam@uhamka.ac.id
}

\begin{abstract}
Conceptual understanding and representation in mathematics are both important mathematical abilities to develop. Conceptual understanding and representation abilities are needed by students to solve mathematical problems. The aim of this research was to describe the representation of mathematics of RME based on student's personality type, the conceptual understanding in RME based on student's personality type. In this research, 8 PGSD students from artisan, idealist, guardian, and rational personality types were selected as subjects. The methods used in this research were tests, interviews, and documentation of personality type questionnaires of the students according to (Keirsey, 1984)). The tests and interviews were analyzed to describe the conceptual understanding and representation abilities of the students. The results of this research were that the students with the rational personality type were very good at identifying and making examples, traits and conditions. Students with the idealist personality type were very good at identifying verbally and in written form. All four personality types' conceptual understanding when identifying and distinguishing concepts was still poor. Meanwhile, for the mathematical representation aspect, all four personality types were very good at visual mathematical representation in the form of figures and tables.
\end{abstract}

Keywords : Mathematical Representation, Conceptual Understanding Ability, Personality Type

\section{INTRODUCTION}

Kesumawati (2008) argues that the number of representations used by students is closely related to their mathematical understanding. The more representations they can use in solving mathematical problems, the more they can make mathematical connections between ideas of problem-solving, mathematical concepts, and the contextual problem. Exploring representation used by students should be a fundamental aspect because teachers who can comprehend students' characteristics will easily master the classroom practices.

A conceptual understanding of mathematics is a very important ability to develop. Conceptual understanding is defined differently by experts. For example, (Chairani, 2012) and (Kesumawati, 2008)) define conceptual understanding as a level of learning in which a person can explain concepts in his or her own words, thus they will be able to easily solve problems. In mathematical education, teacher candidates must comprehensively understand mathematical concepts (Umam, 2018; Umam, Nusantara, Parta, Hidayanto, \& Mulyono, 2019). If the conceptual understanding of mathematics is correct, then the students would not become teachers who give wrong mathematical concepts to their students.

An education that can develop students' understanding of mathematics is Realistic Mathematics Education. According to Hans (1991), mathematics should be relevant to everyday real life. Mathematics needs to be associated with reality and human activity. Mathematics is viewed as human activities which are expressing ideas and mathematical concepts through the guidance of adults (Gravemeijer, 1994; Septiany, Purwanto, \& Umam, 
2015b; Umam et al., 2019). RME refers to various situations and realistic problems. This refers to the reality that would be imagined by students (Septiany, Purwanto, \& Umam, 2015).

Representation is defined differently by experts. For example, research conducted by (Anggraeni \& Suharso, 2019; Brijlall, Bansilal, \& Moore-russo, 2012; Kowiyah \& Mulyawati, 2018; Surahmi, 2016). According to Brijlall et al., (2012), representation can help the mathematical understanding. According to (Kowiyah \& Mulyawati, 2018), representation is communicating ideas through visual forms such as figures or tables, mathematical expressions, and mathematical equations. According to (Surahmi, 2016) representation is incorporating ideas that complete each other and contribute to a global understanding and an understanding of the problem faced, so that the conceptual understanding of mathematics can be clearly understood by students. The representation in this research is the representation through external forms in which students can visually represent their ideas through figures or tables, mathematical expressions, and mathematical equations.

Keirsey (1984) categorizes personality into four types called guardian, artisan, rational, and idealist. According to (Dewiyani S, 2009), the thinking process's characteristics are in accordance with each personality. For example, the idealist type looks at a problem from a broad point of view. A variety of problems are suitable for this type. The rational type has a strong imagination and reasoning skills. Abstract problems are suitable for this type. The artisan type is the type that doesn't give up easily. Clear steps to a problem are suitable for this type. The guardian type is interested in learning materials if the instructor clearly explains the aim of it. Problems that are clear and not long-winded are very suitable for this type.

Research about representation and conceptual understanding has been conducted by (Kesumawati, 2008) and (Wiryanto, 2014). Their research explored the conceptual understanding of mathematics and its representation in mathematics education. According to (Kesumawati, 2008), if students understand a concept, they can define a concept, identify and give an example or not an example of a concept, develop the ability of making mathematical connections between ideas, understand how mathematical ideas are connected to each other so that they have a comprehensive understanding, and use mathematics outside the context of mathematics. Wiryanto (2014) examined the internal representation of conceptual understanding in each Bruner level. But there is still limited research about conceptual understanding and representation of PGSD (Primary School Teacher Education) students based on the theory of personality. Research conducted by (Purwaningsih \& Hidayah, 2017) examined the conceptual understanding with CTL based on artisan, idealist, guardian, and rational personality types.

\section{THE RESEARCH METHODS}

This is descriptive research with a qualitative approach. The subjects were selected based on their personality types according to Keirsey (1984) which were artisan, guardian, idealist, and rational. Purposive sampling was used to choose the subjects, which is a sampling technique from a data source with a certain consideration. The subjects were chosen by consideration of their personality type categorization and interview results. Also, the researchers considered the 
students' ability in expressing their opinions and their thinking process in verbal and written form.

The results of the categorization were 15 students of the artisan type, 20 students of the guardian type, 12 students of the idealist type, and 8 students of the rational type. Based on the categorization of personality types, the researchers selected 2 artisan students, 2 guardian students, 2 idealist students, and 2 rational students.

\section{THE RESULTS OF THE RESEARCH AND THE DISCUSSION}

\section{Guardian Personality Type}

An analysis of the guardian personality's conceptual understanding ability was conducted on subject 1 and subject 2 . The indicators were if the subject was able to identify and make examples and not examples. Subject 1 knew about the basic information of a concept, used simple sentences and focused on geometric figures. When applying it to a sample question, subject 1 gave simple examples according to each formula. Meanwhile, subject 2 knew the basic information of the concept that was used and gave an example of a basic problem by using the geometric formula. Therefore, according to the information, it can be concluded that guardian type subjects identify and make examples based only on the geometric figure, the formula used without giving the concept of the geometric characteristics and did not find the concept about how to find the geometric formula.

In the indicator of identifying the characteristics of a concept and the terms that determine the concept, subject 1 identified the characteristics of a concept based on its geometric figure. Subject 1 changed the shape of an isosceles trapezium by cutting its sides and turning it into a rectangle, a kite, and a parallelogram. Subject 1 gave examples of why the isosceles trapezium shape could not be applied to other four-sided shapes. Meanwhile, subject 2 gave examples of any shape in which the isosceles trapezium formula could be applied by changing the geometric figure. Subject 2 wrote any shape in which the isosceles trapezium formula could not be applied by identifying the characteristics of a four-sided shape. Thus, based on the information given, it can be concluded that guardian subjects could identify the characteristics of a concept and recognize conditions when determining a concept was categorized as good.

In the indicator of comparing and distinguishing concepts., the guardian subjects distinguished and compared a concept with the characteristics of the object according to the given object. In the indicator of identifying concepts verbally and in written form, subject 1 had difficulty when asked to find the area of the shaded part of two adjacent shapes. Subject 1, when finding the area of the shaded part, saw it as two separate figures thus had difficulty in specifying the shaded part and how to find the area of that part. Meanwhile, subject 2 also had difficulty finding the area of the two shaded shapes. Subject 2 could not identify the concept that the area of the shaded part of the adjacent shapes was the area of the un-shaded area subtracted from the whole shape divided by two. Subject 2 only subtracted the area of the unshaded part from the whole area. Therefore, guardian subjects still have difficulty applying suitable concepts or remembering learned concepts until they understand. It can be seen that guardian subjects still were not able to see the application of the concept of area. 
In the indicator of using models, diagrams, and symbols to represent a concept, subject 1 and subject 2 were already capable of using models to represent a concept. This could be seen by their capability of counting the area and price of a carpet for its installation on stairs. The guardian subject could use the concept and procedure of solving problems that were associated with everyday life.

In the indicator of changing the form of one representation to another form, subject 1 had difficulty counting the lawns' area of two nearby neighbors when knowing that they have the same parameters which were 24 meters and the area of one lawn is bigger than the other by 8 $\mathrm{m}^{2}$. Subject 1 assumed that the lawn was square-shaped when obtaining its sides, therefore to find the area $=$ side $\mathrm{x}$ side, meanwhile to find the other area was by adding side ${ }^{2}$ and $8 \mathrm{~m}^{2}$. Subject 1 was not capable of representing a concept consecutively and did not recheck his or her results from what he or she already knew. In contrast with subject 2 , subject 1 obtained the correct answer in accordance with what he or she knew by doing trial-and-error and representation in the form of figures. The guardian subjects still lacked when representing concepts with what they have. It can be concluded that guardian subjects have a weakness with problems in the form of figures, and this subject likes representation in the form of words. This is in accordance with Keirsey's (1984)research as cited by Yuwono (2010) stating that guardian subjects as a whole do not like figures and prefer words based on obtained information that they would afterward use.

The analysis of the mathematical representation ability of the guardian subjects was poor when representing visuals in the form of figures and tables but was good for the aspect of mathematical expressions and equations in written form or words. This is in accordance with research done by Pertiwi, Masrukan, \& Susilo (2014) in which guardian subjects did not have any difficulty in writing mathematical terms. This was because guardian subjects preferred to talk and write concrete things, but if guardian subjects were given drill lessons, they could learn easily if they rewrote the mathematical terms. The mathematical description and statements for guardian subjects were poor. Guardian subjects could not use symbols as the representation for mathematical models in given tasks. Guardian subjects have difficulty in solving problems because they misunderstood mathematical problems.

\section{Rational Personality Type}

An analysis of the conceptual understanding of rational personality types was conducted on subjects 1 and 2. The results of the analysis show that there was a different conceptual understanding ability for each indicator.

In the indicator of identifying and making examples and not examples based on the characteristics of the concept, subject 1 understood the basic information of a concept, understood what was an example and not an example according to the characteristics of the concept. Subject 1 was able to explain what we're not examples by the geometric characteristics, the geometric figure applied the concept of the area of a geometric shape so that a shape's formula could be obtained. Meanwhile, subject 2 understood what was an example and not an example based on the geometric figure and applied the concept of a shape's area without understanding the characteristics of the concept. For subject 2, to find the formula of a rhombus's area, it could be found from the area of a square without having to state the 
characteristics of a square. Overall, the identifying and making examples and not examples of the rational subjects were categorized as good.

In the indicator of identifying characteristics of a concept and recognizing the conditions to determine a concept, subject 1 and subject 2 changed the shape of the isosceles trapezoid into a parallelogram and a rectangle. The rational subject was able to find the formula of the parallelogram and rectangle from the concept of the isosceles trapezoid's area. The rational subject was very good at repeating the concept, could identify the characteristics of a concept and recognize the sufficient conditions of a concept.

The indicator of comparing and distinguishing concepts for the rational subjects was good. Rational subjects could distinguish concepts based on the characteristics of an object. The indicator of identifying concepts verbally and in the written form of the rational aspect was fair. Subject 1 had difficulty when asked to find the area of the shaded part. This subject assumed that there were three shapes which were a rectangle, a kite, and another four-sided shape but was confused when asked to find the area. Meanwhile subject 2 could understand the overall concept of areas. Subject 2 understood that to find the area of the adjacent shapes' shaded part, the area of the unshaded part needs to be subtracted from the whole area and divided by two. Therefore, based on this information, rational subjects did not have difficulty in making mathematical model equations, the rational subjects could remember concepts that could be applied in mathematical equations.

The indicator of using models, figures, and symbols to represent concepts for rational subjects was fair because they were already capable of representing models of figures and analyzing symbols for mathematical equations. But when calculating, subject 1 and subject 2 were not being careful enough when solving the problem. The error in the process of solving the problem and during the interview was because subject 1 did not recheck his or her results. This rational subject could analyze the model of figures and analyze mathematical symbols well. In accordance with research conducted by Pertiwi et al.,( 2014), rational subjects could finish problems correctly even if it has not been taught before by the teacher. Rational subjects usually wrote the reasons that made the readers understand the problem.

In the indicator of changing the form of representation to other forms of representation, subject 2 made a mistake when understanding the problem which resulted in calculation errors. During the interview, when asked why the lawn of the house was in the shape of a square and not other shapes, the subject answered that it could be a rectangle if the width and length was known. If not known, there was confusion in determining which was the width and length. This was because the subject's ability to applying to solutions was very poor. Subject 2 still needed to be guided when solving the problem, thus his or her answer was different from the test and interview. As for the representation ability, subject 2 was already able to represent the figure into mathematical equations. This was different for subject 1 . Subject 1 was fixated on the figure of Mr. Ahmad and Mr. Slamet's lawns that were in the shape of a square. This subject did not recheck his or her answer. This could be seen by his or her answer that the area of Mr. Ahmad's lawn was $44 \mathrm{~m}^{2}$ because the area was $8 \mathrm{~m}^{2}$ bigger than Mr. Slamet's, even though the parameter of the lawn should have been 24 meters. 
The analysis of mathematical representation ability of rational subjects was very good in terms of visual representation in the form of figures and tables along with mathematical expressions or equations, but still poor with descriptions or statements. This could be seen when the subject was asked to find the area of a shape with the area of another. The rational subjects did not only use the figure but also made a mathematical statement or expression. Meanwhile, to give a description or statement, they had difficulty because their level of understanding was still poor.

\section{Idealist Personality Type}

An analysis of the understanding ability of idealist personalities was conducted on subject 1 and subject 2 . In the indicator of identifying and making examples and not examples, subject 1 could explain what was not an example from the figure's shape and subject 2 applied the concept of a shape's geometric area, therefore obtaining the shape's formula without considering the shape's characteristics. Subject 1 assumed that the kite and rhombus had almost the same area as the rectangle but it was different for a square. But from subject 1's answer, it was shown that the rhombus could be for a square. This was because the subject did not understand the characteristics of a square, rectangle, rhombus, and kite. Subject 2 thought that Annisa's opinion was wrong, that to find the kite and rhombus, it could not be applied to squares but rectangles. This subject gave an explanation in the form of figures, in which he or she cut and changed the shape into a rectangle. His or her ability to identifying and making an example was categorized as fair.

In identifying the characteristics of a concept and recognizing the sufficient conditions of the concept, subject 1 and subject 2 identified the conditions of a concept based on the form of the geometric figure, changing its mathematical equation according to the figure that they obtained by finding the formula. When giving an example, subject 1 had difficulty, such as when he or she knew the height and base of an isosceles trapezium, thus to find the area of the isosceles trapezium was by multiplying the parallel side by the height and then dividing it by two. But if the shape was changed into a parallelogram, the subject had difficulty determining which was the base and height, thus obtaining the same area for the isosceles trapezium and parallelogram. Meanwhile, subject 2 did not have difficulty giving an example of his or her ability to identify characteristics of a concept and his or her ability in recognizing a concept's conditions were also categorized as fair.

The indicator of comparing and distinguishing concepts was very poor. This was because the idealist subjects had difficulty in comparing a concept if they knew that the shape had the same perimeter, and determining which had the biggest area. The idealist subjects could correctly answer the shape but made mistakes when doing the calculation because they were not being careful enough.

The indicator of identifying concepts verbally and through the written form for the idealists was categorized as good. Subject 1 and subject 2 could overall understand the concept of areas. The idealist subject could understand that to find the area of the shaded part of adjacent objects, the area of the unshaded part needed to be subtracted from the whole area and divided by two. The idealist subject remembered the concept to make the mathematical model equation. 
The indicator of using models, figures, and symbols to represent concepts for idealist subjects was fair because they were able to represent the model of the figure and analyze the symbol for the mathematical equations. But during the calculation, the idealist subject had difficulty in determining the price of a carpet's area that was needed. The error in the calculation was due to the subject of not being careful enough during the calculation process.

The indicator of changing the form of representation to other forms of representation was categorized as very poor. The idealist subjects were not capable of calculating the lawn area of two nearby neighbors when knowing that they have the same parameter. The idealist subjects assumed that the lawn was in the shape of a square when the sides were obtained, therefore to find the area $=$ side $\mathrm{x}$ side, meanwhile to find the other area was by adding side ${ }^{2}$ and $8 \mathrm{~m}^{2}$. It can be seen that the idealist subjects were not capable of representing a concept consecutively and had difficulty changing the representation of the figure to a description or statement(Borromeo Ferri, 2010; Malaspina, Wilhelmi, \& Barcelona, 2008).

The analysis of the idealist subject's mathematical representation ability in the form of figures and tables was good, fair for mathematical expressions and mathematical equations but were poor for descriptions and statements. It can be seen that the idealist subjects were able to represent the figure for mathematical equations but not for descriptions and statements.

\section{Artisan Personality Type}

An analysis of the understanding of idealist personalities was conducted on subject 1 and subject 2. In the indicator of identifying and making examples and not examples, subject 1 explained examples in the form of figures and analyzed figures that were changed by cutting it to become a rectangle, meanwhile subject 2 assumed that a square that was cut would become a rhombus without considering the shape's characteristics. Subject 1 assumed that a kite and rhombus were almost the same as the area of a rectangle but the different result from subject 2's answer showed that the rhombus could be for a square but did not give a comment for the kite which could be a square or a rectangle. Subject 2 still lacked in the calculation steps thus could not give a correct conclusion.

In identifying the characteristics of a concept and to recognize its sufficient conditions, subject 1 and subject 2 identified the characteristics of a concept based on its geometric figure, changing the mathematical equation according to the figure that they obtained by finding the formula and example of the problem. The artisan subject wrote any shape that could be applied with the formula of an isosceles trapezium by identifying the characteristics of a four-sided shape. Therefore, based on the given information, it can be concluded that the artisan subjects' ability to identify characteristics of a concept and recognize the conditions to determine a concept was categorized as good.

The indicator of comparing and distinguishing a concept was very poor. Same as idealist subjects, this type could correctly answer which shape has the biggest area but made a mistake during the calculation because they were not careful enough. The indicator of identifying concepts verbally and through the written form for the artisan aspect was categorized as good. Artisan subjects could understand the overall concept of areas thus they could make mathematical equation models. 
The indicator of using models, figures, and symbols to represent a concept for artisans subjects was fair because they could represent the model of figures and analyze symbols for mathematical equations. Subject 1 could represent figures and symbols to represent concepts well along with logical arguments. Meanwhile, subject 2 was not being careful enough during the calculation process, thus the interpretation of symbols of the concept was not accurate.

The indicator of changing the form of representation to another form was categorized as fair. The artisan subjects assumed that Mr. Ahmad and Mr. Slamet's lawns were square-shaped but after rechecking, the results that they had were wrong. If the house's lawn was in the shape of a rectangle, how would they count the area of the lawn from two nearby neighbors if they knew that the parameters were the same. It can be seen how artisan subjects were not used to solving these problem-solving questions. Artisan subjects still need to be guided when solving a problem so the answers were different on tests and interviews. As for the representation ability, artisan subjects could represent figures for mathematical equations but not for descriptions or statements.

The analysis of the mathematical representation of artisan subjects was very good for visual representation in the form of figures and tables, and also fair for mathematical expressions and equations but poor for descriptions and statements. This can be seen by the artisan subjects' ability in which they could already represent figures for mathematical equations but not for descriptions and statements.

\section{CONCLUSION AND SUGGESTION}

According to the results and discussion of this research, it can be concluded that the mathematical representation in the RME based on student's personality (1) for the guardian aspect, visual representation in the form of figures or tables was still poor but the mathematical expression or mathematical equations was good, and there were still difficulties in understanding the problem of descriptions and statements, (2) for the rational aspect, the subject's ability of mathematical representation was very good for visual representation in the form of figures or tables along with mathematical expressions and equations but were poor in descriptions and statements, (3) for the idealist aspect, the visual representation in the form of figures and tables was good, fair for mathematical expressions and equations, but still poor in descriptions and statements, (4) for the artisan aspect, the visual representation was very good in the form of figures and tables and was also fair for mathematical expressions and equations but poor in descriptions and statements.

The conceptual understanding of RME based on student's personality types were (1) identifying and making examples and not examples were categorized as good for the rational aspect and was fair for the other three personalities, (2) identifying characteristics of a concept and recognizing the conditions to determine the concept was categorized as fair for the idealist aspect, good for the guardian and artisan aspect, and very good for the rational aspect, (3) comparing and distinguishing concepts were categorized as very poor for the idealist and artisan aspect, and good for guardian and rational, (4) identifying concepts verbally and in written form were categorized as poor for the guardian aspect, fair for the rational aspect, good for the idealist and artisan aspect, (5) using models, diagrams, and symbols to represent a concept was 


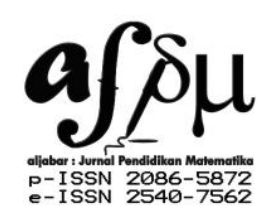

Al-Jabar: Jurnal Pendidikan Matematika

Vol. 10, No. 2, 2019, Hal 201 - 210

categorized as fair for the guardian, rational, idealist, and artisan aspect (6) changing the form of representation to other forms were categorized as very poor for the guardian and idealist aspect, fair for the rational and idealist aspect.

\section{REFERENCES}

Anggraeni, A. R., \& Suharso, R. (2019). Keragaman Media Pembelajaran yang Digunakan Guru Sejarah Dalam Pembelajaran Sejarah Sekolah Menengah Atas Negeri di Kabupaten Rembang Tahun Ajaran 2018 / 2019, 7(1), 59-66.

Borromeo Ferri, R. (2010). On the Influence of Mathematical Thinking Styles on Learners' Modeling Behavior. Journal Für Mathematik-Didaktik, 31(1), 99-118. https://doi.org/10.1007/s13138-010-0009-8

Brijlall, D., Bansilal, S., \& Moore-russo, D. (2012). Exploring teachers ' conceptions of representations in mathematics through the lens of positive deliberative interaction. Pythagoras, 33(2), 1-8. https://doi.org/10.4102/pythagoras.v33i2.165

Chairani, Y. (2012). Peningkatan Mutu Pembelajaran Matematika dan Implementasi Pembelajaran Berbasis Teknologi. Bandung: Rineka Cipta.

Dewiyani S, M. J. (2009). Karakteristik Proses Berpikir Siswa Dalam Mempelajari Matematika Berbasis Tipe Kepribadian. In Prosiding Seminar Nasional Penelitian, Pendidikan dan Penerapan MIPA Fakultas MIPA Universitas Negeri Yogyakarta (pp. 481-492). Yogyakarta: Universitas Negeri Yogyakarta.

Freudenthal, H. (1991). Revisiting Mathematics Education. Boston: Kluwer Academic Publishers.

Gravemeijer. (1994). Developing Realistics Mathematics Education. Utrecht: Freudenthal Institute.

Keirsey, D. (1984). Please Understand Me II Temprament Character Intelegence. Promotheus Nemesis Book.

Kesumawati, N. (2008). Pemahaman Konsep Matematik dalam Pembelajaran Matematika. In Prosiding Seminar Nasional Matematika dan Pendidikan Matematika, Universitas PGRI Palembang (pp. 229-235). Palembang.

Kowiyah, \& Mulyawati, I. (2018). An analysis of primary school students ' representational ability in mathematics based on gender perspective An analysis of primary school students ' representational ability in mathematics based on gender perspective. In Journal of Physics: Conference Series (pp. 1-8). IOP Publishing.

Malaspina, U., Wilhelmi, M. R., \& Barcelona, U. De. (2008). Mathematical Objects Through the Lens of Three, 1 .

Pertiwi, A. D., Masrukan, \& Susilo, B. E. (2014). Analisis Kemampuan Komunikasi Matematis Melalui Pembelajaran Model 4K Berdasarkan Tipe Kepribadian Peserta Didik Kelas VII. Kreano, 5(2), 195-204. 


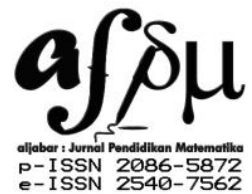

Al-Jabar: Jurnal Pendidikan Matematika

Vol. 10, No. 2, 2019, Hal 201 - 210

Purwaningsih, K., \& Hidayah, I. (2017). Analisis Kemampuan Pemahaman Konsep dalam Pembelajaran Contextual Teaching and Learning Materi Segiempat Ditinjau dari Tipe Kepribadian Peserta Didik. UNNES Journal of Mathematics Education Research, 6(1), 42-51. https://doi.org/10.15294/ujme.v6i1.12642

Septiany, V., Purwanto, S. E., \& Umam, K. (2015a). Influence of learning on realistic mathematics ICT-assisted mathematical problem-solving skills students. In Doctoral Student Consortium (DSC) - Proceedings of the 23rd International Conference on Computers in Education, ICCE 2015.

Septiany, V., Purwanto, S. E., \& Umam, K. (2015b). Influence of learning on realistic mathematics ICT-Assisted mathematical problem-solving skills students. In Work-InProgress Poster - Proceedings of the 23rd International Conference on Computers in Education, ICCE 2015.

Surahmi, E. (2016). Representasi Siswa SMA dalam Memahami Konsep Fungsi Kuadrat ditinjau dari Gaya Kognitif (Visualizer - Verbalizer). SIGMA, 1(2), 57-63.

Umam, K. (2018). Peningkatan Kemampuan Berpikir Matematis Siswa melalui pembelajaran Reciprocal Teaching. Jurnal Pendidikan Matematika Indonesia, 3(2), 57-61.

Umam, K., Nusantara, T., Parta, I. N., Hidayanto, E., \& Mulyono, H. (2019). An Application of Flipped Classroom in Mathematics Teacher Education Programme. International Journal of Interactive Mobile Technologies (IJIM), 13(03), 68. https://doi.org/10.3991/ijim.v13i03.10207

Wiryanto. (2014). Representasi Siswa Sekolah Dasar Dalam Pemahaman Konsep Pecahan. Jurnal Pendidikan Teknik Elektro, 03(03), 593-603.

Yuwono, A. (2010). Profil Siswa SMA dalam Memecahkan Masalah Matematika Ditinjau dari Tipe Kepribadian. Surakarta. 